\title{
A Project-Based Learning Unit Plan: An Inquiry into Frogs
}

\author{
Retha M. Meier, Stephanie A. Hendel \\ School of Education, Saint Louis University, Saint Louis, MO, USA \\ Email: RETHA.MEIER@SLU.EDU
}

How to cite this paper: Meier, R.M. and Hendel, S.A. (2019) A Project-Based Learning Unit Plan: An Inquiry into Frogs. Open Journal of Social Sciences, 7, 70-78. https://doi.org/10.4236/jss.2019.711006

Received: October 15, 2019

Accepted: November 11, 2019

Published: November 14, 2019

Copyright () 2019 by author(s) and Scientific Research Publishing Inc. This work is licensed under the Creative Commons Attribution International License (CC BY 4.0).

http://creativecommons.org/licenses/by/4.0/

\begin{abstract}
In our standards-driven classrooms, teachers are searching for science resources to help them develop positive learning environments and meet district, state, and national standards. Guidelines are provided for creating a project-based learning unit. An inquiry into frogs is used as an example to develop a unit that can be implemented in a third-grade classroom. These guidelines provide a valuable resource for teachers in developing safe, engaging, project-based unit plans.
\end{abstract}

Keywords

Frogs, Inquiry, Project-Based Learning, Science, Unit

\section{Introduction}

Why should teachers use PBL to teach science? Balemen and Keskin [1] found that "students receiving PBL education performed $86.6 \%$ better than those receiving education with traditional methods". Students are motivated as they use PBL to address real world science problems [2] [3] [4]. PBL allows students to become immersed in inquiry while they explore relevant questions of interest in-depth [5]. In addition, student curiosity and wonderment are encouraged [6]. Bell [7] and Chu, Chow, Tse, and Kuhlthau [8] emphasized the importance of student collaboration throughout inquiry-based learning projects. When students are actively involved in the learning process, science becomes meaningful and relevant [5]. Tuttle, Obringer, Czajkowski, and Czerniak [9] found that students become motivated to learn and are encouraged to express their curiosity while engaged in PBL. Finally, teachers also benefit from implementing PBL in their classrooms. They increase their knowledge in science and technology and develop a more positive attitude toward these subjects [2]. 
As state and national science standards change, elementary teachers seek out resources to help them meet standards and develop safe, positive learning environments. Project-based learning is a teaching methodology that allows teachers and students to become actively engaged in science learning and address standards. Krajcik and Czerniak [3] define project-based learning (PBL) as "an approach to teaching science that focuses on children investigating questions and problems that they find meaningful and engaging, and that spark wonderment and curiosity about the world". Hasni et al. [2] reviewed 48 articles from peer-reviewed journals written on the topic of project methods in science and technology published between 2000 and 2014. According to Hasni et al. [2], five primary features include 1) problem/question, 2) investigations/designing activities, 3) collaboration including the community, 4) technology, and 5) final projects.

PBL is not a new concept. The history of using the project method of teaching has been traced to such well-known educators as John Dewey and William Kilpatrick [10]. PBL is rooted in constructivism, a philosophy that focuses on student learning. Students make their own meaning of novel information by connecting to previous knowledge while simultaneously reflecting upon past and present experiences [11].

PBL differs from other teaching strategies in a number of ways. First, students have responsibilities that are quite different from the teacher's responsibilities. Second, student curiosity drives the learning process as they collaborate with teachers to inquire, explore, research, and create. As students ask questions, a driving question emerges that will help drive the project. Krajcik and Czerniak [3] explain that a driving question is an important and meaningful question and one that can be safely explored and interpreted. Third, the traditional teaching model of requiring students to passively receive and recite factual information is no longer sufficient in today's technological era. PBL invites students to solve highly complex, relevant problems that require both a fundamental and $21^{\text {st }}$ century set of skills. Fourth, the central mission of PBL is to develop students into lifelong, successful learners who freely inquire about their world. As teachers use PBL, science no longer remains confined within the four walls of the classroom, but reaches beyond and allows students to take control in their pursuit of knowledge [3].

Teachers are challenged to find a balance between innovative teaching and addressing curriculum standards [12]. By using PBL, this balance is achievable. The National Research Council of the National Academy of Sciences developed and released A Framework for K-12 Science Education in 2011 [13]. The Framework is the basis for the Next Generation Science Standards (NGSS) that outlines knowledge all K-12 students should know in the science discipline. The three dimensions of science learning include disciplinary core ideas (DCIs), cross-cutting concepts (CCCs), and science and engineering practices (SEPs) which, in combination, form performance expectations or learning goals. It is 
understood that students and teachers have great flexibility on how to achieve those performance expectations [14].

Traditional teaching methods dictate role-specific responsibilities for both students and teachers. PBL intentionally blurs these lines, with responsibility split between the teacher and the learner(s). Through collaboration, the teacher creates a work environment where students are "free to develop their own area of interest and determine a way to learn what they want to know" [15].

Typically, teachers provide safety information, support, supervision, and encouragement for students as they develop knowledge and skills. A variety of instructional strategies are used in PBL including direct, indirect, experiential, and independent study [3]. Students learn by "doing science", which includes investigating, experiment under adult supervision, problem solving, collaborating and communicating with peers, and sharing their new knowledge [12]. As the need arises, teachers use a variety of teaching strategies and differentiated learning opportunities throughout the PBL unit. For example, if students need to use a microscope, the teacher will teach microscopy skills at that time. The scalability of this methodology allows teachers to adjust the length of the unit according to time constraints, topics of inquiry, and subject matter. PBL naturally lends itself to numerous opportunities for authentic assessment, both formative and summative, because students participate in the development of the unit and decide their final cumulative project. It is imperative that students receive feedback from their teacher throughout the PBL unit process [4].

Student curiosity is encouraged in PBL as they ask questions, explore, develop a project, and share their findings with an audience. Throughout the unit, data is collected and analyzed. Students interpret results and engage in debates/arguments based upon evidence and interpretations [16]. Scientific literacy evolves as students investigate real-life global issues and develop critical thinking, problem solving, and decision-making skills [3].

\section{Methods}

Developing a PBL Unit: A teacher wants to create a project-based science unit for students in a third-grade class. Where does the teacher begin? In the United States, teachers begin developing their science units by addressing state and/or national science standards. In a project based learning unit, a driving question helps students focus as they investigate a science topic. Driving questions often arise through student curiosity as they play, read books, or while taking nature walks. It is important for students to develop a final product that they can show and discuss in a final presentation. For this reason, students brainstorm and agree upon a final product. Instead of the teacher telling students what they need to learn, students decide what they want to learn and how to divide learning tasks. Students understand they must have evidence of their findings. This often involves providing citations and documentation from their research and science activities. Students learn to think and behave like scientists when they construct 
an argument with evidence. Teachers understand that interesting science activities often keep students engaged in learning and encourage students to think critically as they are immersed in their science projects. It is of utmost importance for the teacher to establish and maintain a safe learning environment for all students. Therefore, teachers must closely supervise students during the learning process. In addition, teachers in the United States are required to provide evidence that students are learning. For this reason, pretests, posttests, checklists, and an evaluation of the final product provide evidence of student learning. To mainstream unit plans the teacher navigates state and/or national science standards to identify where math, social studies, and language arts standards can be integrated. Finally, throughout the unit, students create and develop their final product, which is then presented and celebrated.

We follow and modify a ten-step process for planning a project as outlined by Krajcik and Czerniak [3]. This process includes the following: 1) Begin with Science Standards; 2) Develop a Driving Question; 3) Brainstorm Final Product; 4) Learning Strategies; 5) Constructing an Argument with Evidence; 6) Designing Projects; 7) Science Safety; 8) Assessment; 9) Integration; 10) End Product.

Begin with Science Standards: How does a third-grade teacher determine which science topics are to be taught during the school year (scope) and the sequence? PBL units begin with backward design [17] by identifying learning outcomes (performance expectations). The teacher relies upon district, state, and national science standards to identify learning outcomes. In science classrooms, children often study animals. Since frogs are found all over the world, except Antarctica, they provide an excellent model system for studying animals. If the teacher and students choose "frogs" as their animal of interest, the following NGSS will be a good place to begin: 3-LS4-3 Interdependent Relationships in Ecosystems: Environmental Impacts on Organisms;

https://www.nextgenscience.org/topic-arrangement/3interdependent-relationshi ps-ecosystems-environmental-impacts-organisms.

"Students who demonstrate understanding can: Construct an argument with evidence that in a particular habitat some organisms can survive well, some survive less well, and some cannot survive at all".

Since the NGSS are three-dimensional, Science and Engineering Practices, Disciplinary Core Ideas, and Crosscutting Concepts are identified as follows for this standard:

"Science and Engineering Practices: Engaging in Argument from Evidence: Construct an argument with evidence".

"Disciplinary Core Ideas: LS4.C: Adaptation: For any particular environment, some kinds of organisms survive well, some survive less well, and some cannot survive at all".

"Crosscutting Concepts: Cause and Effect: Cause and effect relationships are routinely identified and used to explain change". 
Develop a Driving Question: It is important for the teacher to talk with students and listen carefully to their interests and thought-provoking questions. For example, if children are playing on the playground and hear frogs calling, a student might ask the following question: "What kinds of frogs live around here?". This question becomes the "driving question" under the overarching topic of Interdependent Relationships in Ecosystems, 3-LS4-3.

https://www.nextgenscience.org/topic-arrangement/3interdependent-relationshi ps-ecosystems-environmental-impacts-organisms.

Brainstorm Final Product: For example, the teacher might ask the students if they are interested in studying frogs within their local community. If so, the first task is for students to select a final product that will serve as the summative assessment piece. Classmates discuss possible final products and decide they would like to write a book about frogs. Additionally, they want to present their book to students in the second-grade class. They intend to invite the school principal and the local conservation agent who occasionally presents lessons to their class.

Learning Strategies: The next step is for the teacher and students to discuss how they would like to approach this learning task. They decide they need to find out what kinds of frogs live in their community by listening for frog calls during different times of the day and evening. The class decides to contact the local zoo and find out if a citizen science program on frogs exists. A local conservation agent will be invited to talk with the class about frogs and how to identify and classify frogs. Depending upon the different types of local frogs, the class will divide into groups. Each group will study one type of frog in depth. In order to provide structure to the book, the teacher offers to guide the students in developing a template so that each group will search for the same information on each of their frog species. The template will address such questions as "Where does the frog live? What does the frog eat? How large is the frog?". As students research background information, students will become curious and ask their own questions. These questions will be written in their science notebooks and addressed in their book. Students might discover that frogs serve as the canaries in the coal mine and ask what this means. They can then do research and discover that frogs are highly susceptible to water pollution. It is important for students to cite references. What is the source of their information? Is this a reliable resource? The teacher can help students learn how to cite references. This information becomes part of constructing an argument and providing evidence that supports their statements. It is important to highlight that this is a routine activity for scientists and engineers (NGSS 3-D SEPS). Each group will become an "expert" on their frog and will present information on that frog to their audience.

Constructing an Argument with Evidence: Keeping in mind the driving question, NGSS 3.LS4-3, and overarching topic, students will "construct an argument with evidence that in a particular habitat some organisms can survive well, some survive less well, and some cannot survive at all". 
https://www.nextgenscience.org/topic-arrangement/3interdependent-relationshi ps-ecosystems-environmental-impacts-organisms. This standard, NGSS 3-LS4-3, can be addressed by discussing tadpoles, frogs, and crickets in aquatic ecosystems. All frogs must return to water to reproduce. Tadpoles survive well because they are adapted to live in the water. They have gills. Adult frogs survive less well because they have lungs. Crickets do not survive at all because they are not aquatic organisms. This information will be added to the frog book. This argument illustrates the NGSS Disciplinary Core Ideas (DCIs) for Adaptation (LS4.C).

Designing Projects: The teacher ensures that student interests, learning activities, and research align with the topic and final product to spark curiosity and excitement. The teacher can introduce models, which can be made using modeling clay to explain and predict. For example, students could create a frog from modeling clay that resembles one found in their local community. Students can then predict what might happen if the frog had an additional leg. Why did a fifth leg grow on the frog? Students can explore the cause of multiple limb growth and possible effects of water pollution and microorganisms on frog development. By doing so, NGSS Crosscutting Concepts for Cause and Effect have been adequately emphasized as well as enhancing critical thinking skills.

Science Safety: It is the teacher's responsibility to carefully examine every activity and project for safety issues [18]. If live frogs are brought into the classroom, they can pose a safety concern. All amphibians may carry Salmonella, a bacterium that can be transmitted either by direct contact (by touching the frog) or indirect contact (by touching the water in which the frog lives). It is also important for students to wash their hands thoroughly with soap and water upon completion of all science activities [19].

Assessment: Assessment is a critical piece of PBL [3]. The teacher and students can work together to develop authentic assessment pieces that provide clear expectations. What do emerging, basic, and proficient mean as students complete lesson plans, do research, and develop a book on frogs? What will be expected during the frog book presentation? Checklists including skill development can be developed for formative assessment. A scoring guide may provide important information for summative assessment covering the final product (the book) and the presentation to the second-grade class and invited guests from the community.

Integration: Additional standards can be addressed when developing lessonplans for this PBL unit on frogs. For example, since students are studying frog size, mathematics standards can be addressed in the lesson plan. Students can compare the size of local frogs with the size of common objects found in their homes or the classroom. Once students understand the length of their frogs, they can determine which common object comes closest to the frog's actual size. If students are studying a small frog, such as a spring peeper (Pseudacris crucifer) measuring 25 to $38 \mathrm{~mm}$ in length, they may compare its length to that of an almond. If the frog is much larger, such as a bullfrog (Lithobates catesbeianus) 
measuring 9 to $15 \mathrm{~cm}$ in length, students may compare its size to an extra-large onion. A similar activity may be used to demonstrate mass. When students compare and contrast, they develop mathematical skills through measuring with a ruler and using a balance. They gain knowledge of the disciplinary core ideas, and build literacy skills through writing new information into their science notebooks and adding entries into their final book project.

End Product: Once the book has been completed, it is necessary to practice prior to giving the presentation. Of course, arrangements were made in the beginning stages and invitations were sent to guests. Students are to be well practiced and prepared with making their presentations and excited about sharing their findings. Upon completion of the presentation, students need to celebrate their success and reflect upon what worked, what did not work, and how the process can be improved. Finally, by participating in PBL, students realize the processes used by real scientists and engineers.

\section{Conclusions}

Teachers often get comfortable with one type of teaching methodology and are reluctant to change. Dole, Bloom, and Kowalske [20] found that students were able to direct their own learning within a few days of using the PBL approach. In addition, inquiry-based learning provides numerous opportunities for differentiated instruction [7] [21], which is very important in the $21^{\text {st }}$ century classroom. Science education is for all students, not simply those who intend to become scientists [16]. It is imperative for all students to gain foundational knowledge in science in order to make well-educated decisions within their homes and communities. As students work collaboratively to create projects, they develop problem solving and time management skills [22], science and technology skills and positive attitudes as well as interest in science and technology [2]. PBL allows students to assume responsibility in the learning process as they develop both academic and social skills [4].

The teacher may initially feel uncomfortable using PBL, especially releasing control and allowing students to determine the direction of their own learning [20]. In addition, teachers especially in elementary schools often "lack relevant disciplinary and pedagogical expertise-and associated confidence-for teaching and learning in these subjects" (i.e. science and/or technology) [23]. The teacher may not have a textbook that provides content and ideas for activities. Therefore, it is the teacher's responsibility to develop clearly defined lesson plans and guide students through the PBL process. By using the guidelines described within this article, teachers will be able to create and implement their own PBL units, learn more about science and technology, and gain more confidence in their knowledge and abilities to serve as a science education leader in their own classrooms.

Why should teachers use PBL to teach science? Students perform better in science [1], are motivated to address real world science issues [2] [3] [4], become 
immersed in inquiry [5], and their curiosity and wonderment are encouraged [6]. Science becomes meaningful and relevant as students engage in PBL [5]. Finally, students become motivated to learn [9].

\section{Acknowledgements}

We sincerely thank Evelyn Wittenauer of the St. Louis Public Schools (SLPS) for participating in PBL.

\section{Conflicts of Interest}

The authors declare no conflicts of interest regarding the publication of this paper.

\section{References}

[1] Balemen, N. and Keskin, M. (2018) The Effectiveness of Project-Based Learning on Science Education: A Meta-Analysis Search. International Online Journal of Education and Teaching, 5, 849-865.

[2] Hasni, A., Bousadra, F., Belletête, V., Benabdallah, A., Nicole, M.-C. and Dumais, N. (2016) Trends in Research on Project-Based Science and Technology Teaching and Learning at K-12 Levels: A Systematic Review. Studies in Science Education, 52, 199-231. https://doi.org/10.1080/03057267.2016.1226573

[3] Krajcik, J.S. and Czerniak, C.M. (2018) Teaching Science in Elementary and Middle School: A Project-Based Learning Approach. Fifth Edition, Routledge, Taylor \& Francis Group, New York and London.

[4] Shin, M.-H. (2018) Effects of Project-Based Learning on Students' Motivation and Self-Efficacy. English Teaching, 73, 95-112. https://doi.org/10.15858/engtea.73.3.201809.95

[5] Krajcik, J., McNeill, K. and Reiser, B. (2007) Learning-Goals-Driven Design Model: Developing Curriculum Materials that Align with National Standards and Incorporate Project-Based Pedagogy. Science Education, 92, 1-32. https://doi.org/10.1002/sce.20240

[6] Nordine, J., Krajcik, J., Fortus, D. and Neumann, K. (2019) Using Storylines to Support Three-Dimensional Learning in Project-Based Science. Science Scope, 42, 86-92. https://doi.org/10.2505/4/ss19_042_06_86

[7] Bell, S. (2010) Project-Based Learning for the 21st Century: Skills for the Future. Clearing House. A Journal of Educational Strategies, Issues, and Ideas, 83, 39-43. https://doi.org/10.1080/00098650903505415

[8] Chu, S., Chow, K., Tse, S. and Kuhlthau, C. (2008) Grade 4 Students' Development of Research Skills through Inquiry-Based Learning Projects. School Libraries Worldwide, 14, 10-37.

[9] Tuttle, N., Obringer, M., Czajkowski, K. and Czerniak, C. (2104) What Is a Foot Under Your Feet? A Project-Based Science Unit for Fifth Graders Explores Soil Quality. Science and Children, 3, 49.

[10] Knoll, M. (1997) The Project Method: Its Vocational Education Origin and International Development. Journal of Industrial Teacher Education, 34, 59-80.

[11] Glatthorn, A.A., Boschee, F., Whitehead, B.M. and Boschee, B.F. (2019) Current Developments in the Subject Fields. In, Curriculum Leadership, Strategies for De- 
velopment and Implementation, 5th Edition, Sage, Los Angeles, CA.

[12] Toolin, R.E. (2004) Striking a Balance between Innovation and Standards: A Study of Teachers Implementing Project-Based Approaches to Teaching Science. Journal of Science Education and Technology, 13, 179-187. https://doi.org/10.1023/B:JOST.0000031257.37930.89

[13] https://www.nextgenscience.org/framework-k-12-science-education

[14] For States (Get To Know) (2013) Next Generation Science Standards. https://www.nextgenscience.org

[15] Petrosino, A.J. (2004) Integrating Curriculum, Instruction, and Assessment in Project-Based Instruction: A Case Study of an Experienced Teacher. Journal of Science Education and Technology, 13, 447-460. https://doi.org/10.1007/s10956-004-1466-y

[16] Krajcik, J. (2015) Project-Based Science. Science Teacher, 82, 25-27. https://doi.org/10.2505/4/tst15_082_01_25

[17] Wiggins, G. and McTighe, J. (2011) The Understanding by Design Guide to Creating High-Quality Units. Association for Supervision and Curriculum Development, Alexandria, VA, USA.

[18] Meier, R., Murdick, N. and Lytle, C. (2014) The Safety of Science Activities in an Inclusive Elementary Classroom. Open Journal of Social Science, 2, 278-288. https://doi.org/10.4236/jss.2014.29046

[19] Edens, R., Murdick, N. and Gartin, B. (2003) The Use of Universal Precautions In The Classroom. Teaching Exceptional Children, 35, 62-66. https://doi.org/10.1177/004005990303500410

[20] Dole, S., Bloom, L. and Kowalske, K. (2016) Transforming Pedagogy: Changing Perspectives from Teacher-Centered to Learner-Centered. Interdisciplinary Journal of Problem-Based Learning, 10. https://doi.org/10.7771/1541-5015.1538

[21] Han, S., Capraro, R. and Capraro, M. (2014) How Science, Technology, Engineering, and Mathematics (STEM) Project-Based Learning (PBL) Affects High, Middle, and Low Achievers Differently: The Impact of Student Factors on Achievement. International Journal of Science and Mathematics Education, 13, 1089-1113. https://doi.org/10.1007/s10763-014-9526-0

[22] Mahasneh, A.M. and Alwan, A.F. (2018) The Effect of Project-Based Learning on Student Teacher Self-Efficacy and Achievement. International Journal of Instruction, 11, 511-524. https://doi.org/10.12973/iji.2018.11335a

[23] Bencze, J.L. (2010) Promoting Student-Led Science and Technology Projects in Elementary Teacher Education: Entry into Core Pedagogical Practices through Technological Design. International Journal of Technology and Design Education, 20, 43-62. https://doi.org/10.1007/s10798-008-9063-7 